\title{
KARAKTERISTIK PARAMETER OSEANOGRAFI FISIKA-KIMIA PERAIRAN PULAU KERUMPUTAN KABUPATEN KOTABARU KALIMANTAN SELATAN
}

\author{
Dafiuddin Salim, Yuliyanto, Baharuddin \\ Fakultas Perikanan dan Kelautan, Universitas Lambung Mangkurat, \\ Kalimantan Selatan \\ Email:dsalim@unlam.ac.id
}

Received August 2017, Accepted September 2017

\begin{abstract}
ABSTRAK
Kondisi dan dinamika perairan laut sangat dipengaruhi antara lain parameter oseanografi fisik dan kimia. Parameter oseanografi fisik dan kimia ini penting karena berpengaruh terhadap kondisi dan kualitas perairan Pulau Kerumputan Kabupaten Kotabaru. Seperti diketahui perairan Kabupaten Kotabaru dan pulau-pulau kecilnya sangat dinamis karena terletak antara Laut Jawa dan Selat Makassar. Perairan ini semakin strategis karena dimanfaatkan dalam berbagai bidang seperti pelayaran, perikanan tangkap, transportasi, pertambangan dan lain sebagainya. Adanya dinamika perairan dan pemanfaatan ruang laut ini akan mempengaruhi kondisi perairan secara fisik dan kimia. Dengan kondisi perairan seperti ini diperlukan kajian oseanografi sehingga diperoleh informasi dasar karakteristik oseanografi fisik-kimia pada perairan Pulau Kerumputan dan sekitarnya. Penelitian ini bertujuan untuk mengetahui karakteristik parameter fisika dan kimia perairan Pulau Kerumputan. Parameter fisik-kimia perairan yang diukur adalah arus, kedalaman, kecerahan, kekeruhan, suhu, $\mathrm{pH}$, oksigen terlarut, salinitas, tekstur sedimen, nitrat dan fosfat. Analisis data dilakukan secara deskriptif. Hasil penelitian ini didapatkan suhu pada kisaran $27-30^{\circ} \mathrm{C}$, salinitas $28-29$ $\%$, perairan cukup keruh dan terlindung dari gelombang, kecepatan arus yang relatif kuat, nutrient Nitrat $0,4-1,5 \mathrm{mg} / \mathrm{l}$ dan Posfat $0,09-0,15 \mathrm{mg} / \mathrm{l}$, nilai rerata ukuran butir substrat (mean) 1,214 dengan tekstur pasir. Hasil analisa ini secara umum menunjukkan kondisi baik dan cocok untuk kehidupan biota laut sesuai standar baku mutu yang sudah ditetapkan oleh Kementrian Negara Lingkungan Hidup (Kepmen LH) No. 51 Tahun 2004.
\end{abstract}

Kata kunci: Fisik-Kimia, Kerumputan-Kotabaru, Biota Laut.

\section{ABSTRACT}

The conditions and dynamics of marine waters are strongly influenced among other parameters of physical and chemical oceanography. This 
physical and chemical oceanography parameter is important because it affects the condition and quality of waters of Kerumputan Island of Kotabaru Regency. As is known the waters of Kotabaru Regency and its small islands are very dynamic because it is located between the Java Sea and Makassar Strait. These waters are increasingly strategic because they are utilized in various fields such as shipping, capture fisheries, transportation, mining and so forth. The existence of the dynamics of the waters and the utilization of sea space will affect the condition of the waters physically and chemically. With the condition of such waters are required physical and chemical oceanographic studies to obtain basic information characteristics of physical-chemical oceanography on Kerumputan Island waters and surrounding areas. This study aims to determine the characteristics of physical and chemical parameters on Kerumputan Island. Physical-chemical parameters of waters measured are current, depth, brightness, turbidity, temperature, $\mathrm{pH}$, dissolved oxygen, salinity, sediment texture, nitrate and phosphate. Data analysis was done descriptively. The results of this study obtained temperatures in the range $27-30^{\circ} \mathrm{C}$, salinity $28-29 \%$, waters quite cloudy and protected from waves, relatively strong current velocity, nutrient Nitrate 0.4-1.5 mg/l and Phosphate 0.09-0 , $15 \mathrm{mg} / \mathrm{l}$, mean value of grain size of substrate 1,214 with sand texture. The results of this analysis generally indicate good and suitable conditions for marine life in accordance with the standard quality standards set by the Ministry of Environment (Kepmen LH) no. 51 of 2004.

Keywords: Physical-Chemical, Kerumputan-Kotabaru, Marine Life.

\section{PENDAHULUAN}

Perairan Kalimantan Selatan, pada umumnya memiliki karakteristik perairan yang berbeda dengan perairan lainnya di Indonesia bagian timur. Di perairan ini, khususnya perairan Pulau Kerumputan Kabupaten Kotabaru memiliki perairan yang cenderung keruh sepanjang musim. Tingkat kekeruhan di perairan ini cukup tinggi disebabkan banyaknya masukan (run off) sungai dari daratan ke perairan laut dan perairan ini semakin keruh oleh pengaruh hempasan ombak pada musim tenggara.

Perairan Pulau Kerumputan yang terletak dan dipengaruhi langsung oleh Selat Makassar dan Laut Jawa menjadikan wilayah ini sangat strategis dalam bidang pelayaran, perikanan tangkap, transportasi dan pertambangan. Meski demikian, kegiatan ini dapat berpotensi terhadap pencemaran laut. Perairan Pulau Kerumputan yang juga berdekatan dengan daratan utama Kalimantan tidak lepas dari pengaruh aliran sungai. Potensi buangan aliran limbah cair dan sampah serta sedimentasi dari sungai-sungai ini bersifat antrophogenik (Irawan dan Lily, 2013). Pengaruh dari daratan ini banyak menyuplai zat organik yang merupakan sisa buangan dari berbagai aktivitas manusia seperti rumah tangga, pemukiman, peternakan dan pertanian (Muchtar, 2012).

Adanya aktivitas dan pemanfaatan tersebut diatas, baik secara langsung dan tidak langsung dapat mempengaruhi parameter oseanografi 
fisika dan kimia perairan. Dimana kondisi oseanografi suatu perairan dapat dipengaruhi oleh faktor eksternal seperti laut lepas yang mengelilinginya dan daratan berupa aliran air tawar menuju laut dari sungai. Adapun faktor internal adalah topografi dasar perairan (Yolanda, dkk., 2016). Dengan demikian, kondisi sifat fisik dan kimia pada perairan sangat mempengaruhi keberadaan biota perairan yang hidup di wilayah perairan tersebut dalam mencari makan, berpijah, berlindung dan pembesaran.

Oleh karena perairan Pulau Kerumputan yang sangat kompleks dan dinamis dipengaruhi oleh DAS dan massa air (Selat Makassar dan Laut Jawa), maka diperlukan peneltian yang berkaitan dengan karakteristik fisika dan kimia perairan. Tujuan dari penelitian ini adalah untuk mengetahui karakteristik oseanografi fisika-kimia pada perairan Pulau Kerumputan.

\section{MATERI DAN METODE}

Kegiatan penelitian dilaksanakan pada bulan Juni - Agustus 2017 di perairan Pulau Kerumputan Kabupaten Kotabaru dengan wilayah pengamatan didasarkan pada sebaran terumbu sekitar pulau. Data primer dalam studi ini merupakan data yang diperoleh dari pengamatan langsung di lokasi penelitian melalui survei. Parameter penelitian fisika perairan meliputi arus, suhu, kekeruhan, kecerahan, kedalaman dan substrat perairan. Sedangkan parameter kimia perairan meliputi oksigen terlarut, salinitas, $\mathrm{pH}$, posfat dan nitrat. Data sekunder merupakan data yang didapatkan dari penelitian sebelumnya berupa laporan dan referensi lainnya. Pengukuran parameter fisika-kimia perairan dilakukan secara insitu dan analisis sedimen, kekeruhan, nitrat dan fosfat dilakukan di laboratorium. Data yang diperoleh dianalisis di laboratorium. Hasil pengumpulan data dianalisis secara deskriftif kualitatif dan kuantitatif dalam bentuk tabel maupun grafik/diagram.

\section{HASIL DAN PEMBAHASAN}

\section{Parameter Fisika Perairan}

\section{Pola dan Arah Arus}

Pola dan kecepatan arus pasang surut ini dianalisis berdasarkan model SMS (Surface Modeling System). Model SMS menggunakan persamaan kontinuitas dan persamaan momentum dengan perata-rataan kedalaman dalam memodelkan pola dan kecepatan arus pasut. Penyelesaian persamaan tersebut menggunakan pendekatan metode beda hingga (finite difference). Dari hasil model tersebut diperoleh empat bentuk pola arus pasang surut yang terjadi di perairan Pulau Kerumputan dan sekitarnya yakni pola arus saat maksimum, pola arus pasang surut saat menuju pasang, pola arus saat minimum dan pola arus pasang surut saat menuju surut (Gambar 1). 


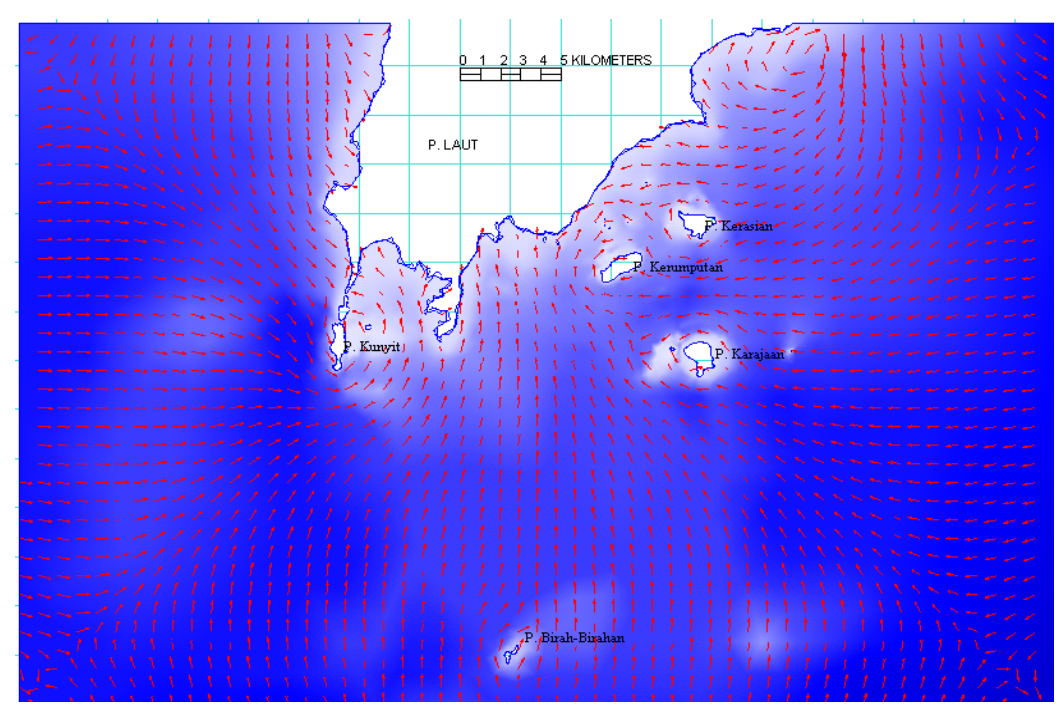

Gambar 1. Pola dan arah arus Pulau Kerumputan dan sekitarnya

Berdasarkan Gambar 1 menunjukkan bahwa saat mencapai pasang maksimum, arus bergerak dari utara menuju selatan dan dari arah timur memasuki pantai (menuju barat) dengan kecepatan maksimum mencapai $0,266 \mathrm{~m} / \mathrm{s}$. Demikian halnya juga dengan arah pada saat menuju pasang kecepatan maksimum mencapai $0,604 \mathrm{~m} / \mathrm{s}$. Kondisi yang berbeda terjadi pada saat surut dan menuju surut, dimana arah arus bergerak dari barat menuju timur (meninggalkan pantai), dengan kecepatan masing-masing $0,128 \mathrm{~m} / \mathrm{s}$ dan $0,214 \mathrm{~m} / \mathrm{s}$. Hasil pola arus menunjukkan bahwa pengaruh arus Selat Makassar yang dominan bergerak ke selatan sangat berpengaruh terhadap pola arus yang terjadi di perairan Gugusan Pulau Laut Kepulauan. Hasil ini juga ditunjukkan oleh adanya sedimen dasar yang di dominasi oleh pasir berlumpur yang berasal dari wilayah utara terutama dari Selat Sebuku (Dinas Perikanan dan Kelautan Prov. Kalsel, 2015). Pengukuran saat penelitian didapatkan kecepatan arus rata-rata $0,10 \mathrm{~m} / \mathrm{s}$ (Tabel 1 ) dengan arah arus cenderung ke utara atau ke daratan utama Pulau Laut Kabupaten Kotabaru.

\section{Suhu}

Hasil pengukuran suhu disekitar perairan lokasi studi menunjukkan nilai berkisar $27{ }^{\circ} \mathrm{C}-30{ }^{\circ} \mathrm{C}$ dengan rata-rata $28^{\circ} \mathrm{C}$ (Tabel 1). Suhu dengan kisaran yang berbeda ini diduga karena faktor perbedaan waktu pada saat pengamatan seperti yang dijelaskan oleh Effendi (2003) yakni suhu perairan juga dipengaruhi oleh musim, lintang (latitude), ketinggian dari permukaan laut (altitude), waktu dalam hari, sirkulasi udara, penutupan awan dan aliran serta kedalaman badan air. Perubahan suhu berpengaruh terhadap proses kimia, fisika dan biologi air. Lebih lanjut Patty (2013) menyatakan pola arus yang berubah secara mendadak dapat menurunkan nilai suhu pada air. Kisaran suhu diperairan dangkal lebih besar daripada perairan laut dalam, karena mengalami banyak pergolakan yang disebabkan oleh angin dan dinamika oseanografi fisika lainnya 
(Odum, 1994). Fenomena-fenomena seperti ini merupakan fakta yang terjadi pada daerah perairan Pulau Kerumputan dan sekitarnya.

\section{Kekeruhan}

Sifat optik air yang ditentukan berdasarkan banyaknya cahaya yang diserap dan dipancarkan oleh bahan-bahan yang terdapat dalam air merupakan parameter kekeruhan. Kekeruhan disebabkan oleh bahan organik dan anorganik baik tersuspensi maupun terlarut seperti lumpur, pasir, bahan organik seperti plankton dan mikroorganisme lainnya (Irawan dan Lily, 2013). Hasil analisis parameter kekeruhan menunjukkan kisaran 0,66 - 4,21 NTU (Tabel 1). Kekeruhan di perairan ini tergolong rendah dan tidak melebihi baku mutu air laut untuk kegiatan kehidupan biota laut (Kepmen LH No 51 Tahun 2004).

\section{Kecerahan}

Kecerahan merupakan tingkat intensitas cahaya matahari yang menembus suatu perairan, sehingga hal ini sangat dipengaruhi oleh kekeruhan. Dari hasil pengukuran lapangan dengan menggunakan sechi disk, menunjukkan kecerahan berkisar 0,5 m sampai dengan $2 \mathrm{~m}$ (Tabel 1) atau $25 \%$ sampai $100 \%$ (dalam skala batas kecerahan dibagi kedalaman). Kecerahan yang mencapai $100 \%$ umumnya pada kedalaman $<5 \mathrm{~m}$, sedangkan perairan yang lebih dalam $(>10 \mathrm{~m})$ tingkat kecerahannya lebih kecil yakni $<70 \%$ yang disebabkan oleh kemampuan tingkat intensitas cahaya matahari yang menembus perairan rata-rata $<10$ m. Rendahnya tingkat kecerahan di lokasi kajian disebabkan oleh wilayah ini merupakan daerah selat antara daratan Pulau Laut Kabupaten Kotabaru dan Pulau Kerumputan (Selat Kerumputan) yang mana banyaknya aliran sungai dari Pulau Laut maupun pengaruh Pulau Sebuku. Hal ini terbukti dari substrat dasar perairan yang didominasi lumpur dan pasir halus. Selain itu, secara pengamatan visual yang dilakukan terhadap substrat dasar daerah lokasi studi menunjukkan bahwa batu karang mati dan pasir merupakan substrat dasar yang dominan.

Tabel 1. Kondisi fisika-kimia perairan

\begin{tabular}{|c|c|c|c|c|c|c|c|c|}
\hline \multirow[t]{2}{*}{ Parameter } & \multicolumn{7}{|c|}{ Stasiun Pengamatan } & \multirow{2}{*}{$\begin{array}{l}\text { Rata- } \\
\text { rata }\end{array}$} \\
\hline & 1 & 2 & 3 & 4 & 5 & 6 & 7 & \\
\hline Suhu $\left({ }^{\circ} \mathrm{C}\right)$ & 27 & 30 & 28 & 28 & 28 & 28 & 27 & 28 \\
\hline $\begin{array}{l}\text { Kecerahan } \\
\text { (meter) }\end{array}$ & 1.5 & 1.4 & 2 & 0.5 & 2 & 2 & 1 & 1,49 \\
\hline $\begin{array}{l}\text { Salinitas } \\
\text { (ppm) }\end{array}$ & 28 & 29 & 28 & 28 & 28.2 & 28.2 & 29 & 28,34 \\
\hline Arus (m/s) & 0.08 & 0.04 & 0.05 & 0.04 & 0.2 & 0.2 & 0.08 & 0,10 \\
\hline $\begin{array}{l}\text { Kekeruhan } \\
\text { (NTU) }\end{array}$ & 0.66 & 1.05 & 3.52 & 3.13 & 2.21 & 4.21 & 2.25 & 2,43 \\
\hline $\begin{array}{l}\text { Ukuran butir } \\
\text { sedimen }(\phi)\end{array}$ & 0.683 & 0.878 & 0.605 & 0.772 & 1.601 & $\begin{array}{l}1.56 \\
7\end{array}$ & 0.521 & 0,95 \\
\hline $\begin{array}{l}\text { Kedalaman } \\
\text { (meter) }\end{array}$ & 4 & 1.4 & 5.5 & 0.5 & 2 & 2 & 1 & 2,34 \\
\hline
\end{tabular}




\begin{tabular}{lllllllll}
\hline DO $(\mathrm{mg} / \mathrm{l})$ & 7.2 & 7.2 & 7.5 & 7.2 & 6.8 & 6.8 & 7.2 & 7,13 \\
$\mathrm{Ph}$ & 7.7 & 7.7 & 7.7 & 7.7 & 7.5 & 7.5 & 7.7 & 7,64 \\
Posfat & 0,109 & 0,10 & 0,117 & 0,112 & 0,123 & 0,11 & 0,12 & 0,11 \\
$(\mathrm{mg} / \mathrm{l})^{\star}$ & 8 & & 5 & 1 & 1 & & & \\
Nitrat $(\mathrm{mg} / \mathrm{l})^{\star}$ & 0,5 & 0,5 & 0,8 & 0,7 & 0,6 & 0,8 & 0,7 & 0,66 \\
\hline
\end{tabular}

Sumber: - Hasil analisis dan pengukuran tahun 2017

- * Dinas Perikanan dan Kelautan Prov. Kalsel, 2015

\section{Kedalaman}

Hasil pengukuran kedalaman di perairan Pulau Kerumputan menunjukkan perairan yang landai (datar). Kedalaman perairan dengan kategori datar merupakan kedalaman dengan interval $0-5 \mathrm{~m}$. Kedalaman dengan interval 0-5 m pada umumnya didapatkan pada perairan yang berhadapan langsung dengan daratan Pulau Laut Kabupaten Kotabaru seperti pada perairan Pulau Kerumputan. Meski demikian pada wilayah lainnya sekitar Pulau Kerumputan memiliki kedalaman yang bervariasi seperti sisi timur Pulau Kerayaan dan Pulau Ondong yang langsung berhadapan dengan Selat Makassar yang mencapai $>25 \mathrm{~m}$, kedalaman antara Pulau Kerayaan dan Kerumputan (Selat Kerayaan) bisa mencapai kedalaman $22 \mathrm{~m}$, kedalaman antara Pulau Kerayaan dan Pulau Tepian Mataja mencapai $13 \mathrm{~m}$, kedalaman antara Pulau Kerasian dan Pulau Kerumputan mencapai $11 \mathrm{~m}$, sedangkan kedalaman antara Pulau Kerumputan dan Pulau Laut mencapai $8 \mathrm{~m}$ (Dinas Perikanan dan Kelautan Prov. Kalsel, 2015), sebagaimana disajikan pada Gambar 2.

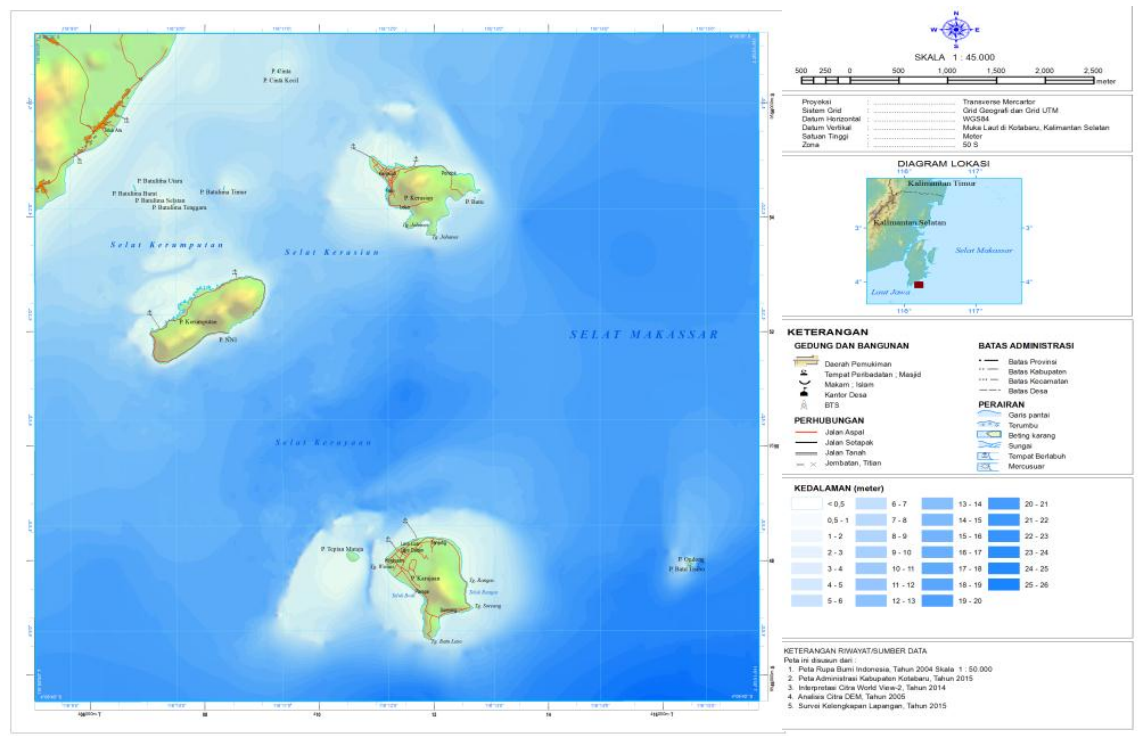

Gambar 2. Peta kedalaman (batimetri) Pulau Kerumputan dan perairan sekitarnya

\section{Substrat Perairan}

Secara umum, komposisi subtrat pantai terdiri atas pasir dan fraksi karang serta pecahan moluska. Karakteristik tersebut dibentuk oleh erosi batuan daratan dan proses alami fisik karang maupun kerang-kerangan 
(moluska). Hasil analisis menunjukkan bahwa butiran sedimen di lokasi kajian lebih dominan dalam ukuran 0,125 mm mencapai 26,83 \% kemudian ukuran sedimen $0.5 \mathrm{~mm}$ mencapai 20,47 \% (Tabel 2). Berdasarkan ukuran butiran sedimen tersebut dan dihubungkan dengan ukuran butiran sedimen skal Wentworth (English et.al., 1994), menunjukkan bahwa ukuran butiran tersebut termasuk dalam klasifikasi Pasir dengan rerata ukuran butir substrat (mean) 1,214 (Tabel 3). Hal tersebut mengindikasikan adanya akumulasi sedimen tersebut berasal dari muara sungai dan perairan sebelah utara Kecamatan Sebuku serta dari Laut Jawa dan Selat Makassar.

Tabel 2. Persentase ukuran butir substrat perairan Pulau Kerumputan

\begin{tabular}{lllllllllll}
\hline Lokasi & \multicolumn{9}{c}{ Ayakan $(\mathrm{mm})$} & \multicolumn{5}{c}{ Jumlah } & Ket \\
\cline { 2 - 8 } & 2 & 1 & 0.5 & 0.25 & 0.125 & 0.063 & $<0,063$ & & \\
St. 1 & 38.9 & 6.33 & 12.43 & 26.61 & 14.87 & 0.58 & 0 & 99.72 & pasir \\
St. 2 & 11.7 & 14.43 & 30.92 & 14.32 & 23.51 & 4.29 & 0.03 & & pasir \\
St. 3 & 26.2 & 11.99 & 21.3 & 17.62 & 20.11 & 2.59 & 0 & 99.81 & pasir \\
St. 4 & 14.35 & 11.61 & 19.7 & 19.56 & 33.2 & 1.18 & 0 & 99.6 & pasir \\
St. 5 & 13.6 & 6.49 & 12.48 & 17.22 & 47.12 & 2.88 & 0 & 99.79 & pasir \\
St. 6 & 15.76 & 7.41 & 22.06 & 32.42 & 19.88 & 2.29 & 0 & 99.82 & pasir \\
St. 7 & 20.64 & 27.13 & 40.09 & 9.23 & 2.65 & 0.06 & 0 & 99.8 & pasir \\
$\%$ & 18.17 & 15.07 & 20.47 & 17.64 & 26.83 & 1.78 & 0.003 & 99.963 & \\
\hline
\end{tabular}

Sumber: Hasil analisis, 2017

Tabel 3. Ukuran butiran substrat D50 di perairan Pulau Kerumputan

\begin{tabular}{|c|c|c|c|c|c|c|c|c|}
\hline \multirow[t]{3}{*}{ St } & \multirow{2}{*}{\multicolumn{2}{|c|}{ D50 }} & \multirow{3}{*}{\multicolumn{2}{|c|}{ Nama Sedimen }} & \multirow[t]{3}{*}{ Tekstur } & \multicolumn{3}{|c|}{ Distribusi } \\
\hline & & & & & & Ukuran & Butir & \\
\hline & $(\mu \mathrm{m})$ & $(\phi)$ & & & & Gravel & Pasir & Lumpur \\
\hline 1 & 623.1 & 0.683 & $\begin{array}{l}\text { Poorly } \\
\text { Very } \\
\text { Sand }\end{array}$ & $\begin{array}{l}\text { Sorted } \\
\text { Coarse }\end{array}$ & Sand & $0 \%$ & $100 \%$ & $0 \%$ \\
\hline 2 & 544.1 & 0.878 & $\begin{array}{l}\text { Poorly } \\
\text { Coarse }\end{array}$ & $\begin{array}{l}\text { Sorted } \\
\text { Sand }\end{array}$ & Sand & $0 \%$ & $100 \%$ & $0 \%$ \\
\hline 3 & 585.5 & 0.772 & $\begin{array}{l}\text { Poorly } \\
\text { Very } \\
\text { Sand }\end{array}$ & $\begin{array}{l}\text { Sorted } \\
\text { Coarse }\end{array}$ & Sand & $0 \%$ & $100 \%$ & $0 \%$ \\
\hline 4 & 329.6 & 1.601 & $\begin{array}{l}\text { Poorly } \\
\text { Fine Sar }\end{array}$ & $\begin{array}{l}\text { Sorted } \\
\text { nd }\end{array}$ & Sand & $0 \%$ & $100 \%$ & $0 \%$ \\
\hline 5 & 179.9 & 2.475 & Poorly & Sorted & Sand & $0 \%$ & $100 \%$ & $0 \%$ \\
\hline
\end{tabular}




\begin{tabular}{ccclcccc}
\hline 6 & 337.5 & 1.567 & $\begin{array}{l}\text { Fine Sand } \\
\text { Poorly Sorted } \\
\text { Medium Sand } \\
7\end{array} \quad 696.9$ & 0.521 & $\begin{array}{l}\text { Moderately } \\
\text { Sorted Very } \\
\text { Coarse Sand }\end{array}$ \\
\hline
\end{tabular}

Sumber: Hasil analisis 2017

\section{Parameter Kimia Perairan}

\section{Oksigen Terlarut}

Hasil pengukuran oksigen terlarut (DO) yang berkisar antara 6,8 $\mathrm{mg} / \mathrm{l}$ sampai dengan $7,5 \mathrm{mg} / \mathrm{l}$ dengan rata-rata $7,1 \mathrm{mg} / \mathrm{l}$ (Tabel 1). Jika mengacu pada Kepmen LH No. 51 Tahun 2004 maka nilai DO di perairan ini cukup baik atau memenuhi baku mutu. Hal ini menunjukkan bahwa pengaruh perairan sekitarnya terutama gelombang sangat berpengaruh sebagai oksigenasi air laut. Hasil peenelitian ini tidak jauh beda dengan hasil yang didapatkan pada penelitian sebelumnya dimana rata-rata DO yang didapatkan di perairan Pulau Kerumputan sebesar 7,2 mg/l (Gambar 3) (Dinas Perikanan dan Kelautan Prov. Kalsel, 2015). Hal ini berarti perubahan nilai DO yang terjadi tidak terlalu mencolok. Sebaran DO di perairan Pulau Kerumputan dan sekitarnya disajikan pada Gambar 3.

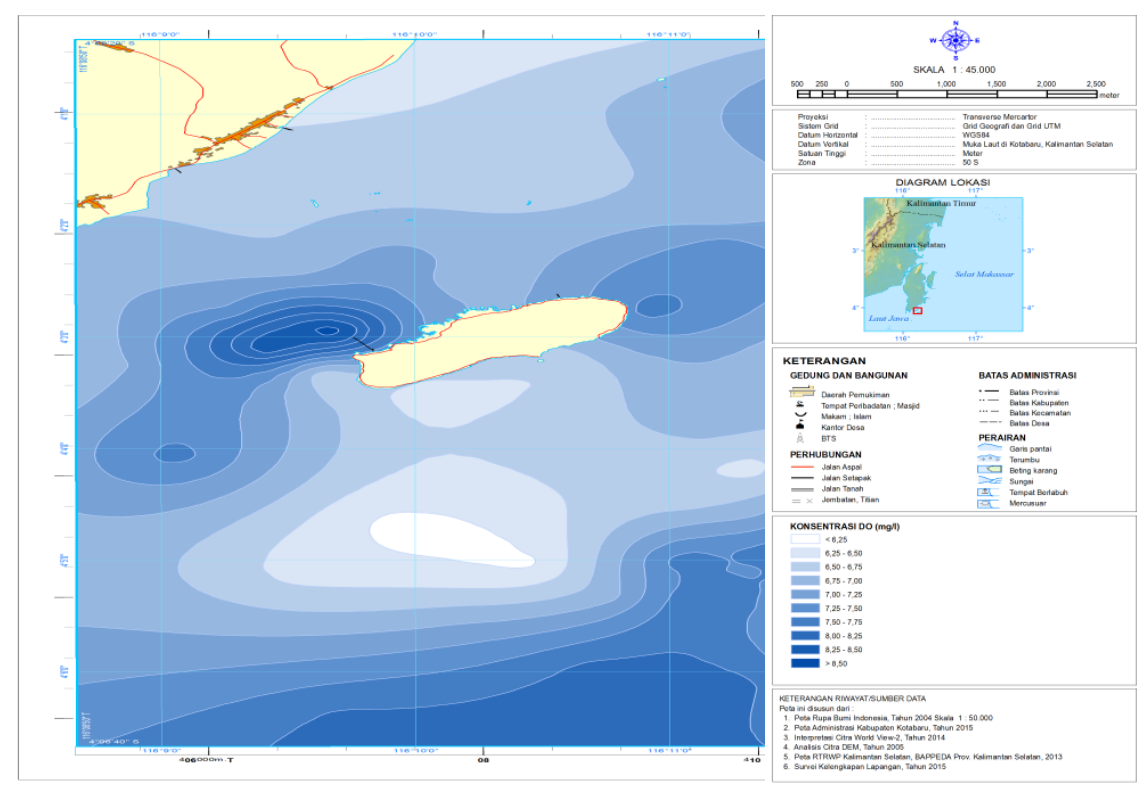

Gambar 3. Sebaran DO di perairan Pulau Kerumputan dan sekitarnya

\section{Posfat}

Berdasarkan hasil penelitian yang pernah dilakukan di lokasi kajian, kadar fosfat di lapisan permukaan perairan Pulau Kerumputan berkisar antara 0,10-0,12 $\mathrm{mg} / \mathrm{l}$. Kisaran fosfat tersebut menunjukkan nilai yang 
tinggi dari yang ditetapkan Baku Mutu Air Laut oleh Kepmen LH No 51 Tahun 2004 untuk kelangsungan biota laut yakni < 0,015 mg/l (Dinas Perikanan dan Kelautan Prov. Kalsel, 2015). Tingginya kadar fosfat di perairan Pulau Kerumputan dan perairan sekitarnya sangat dipengaruhi oleh aktifivitas manusia di daratan utama Pulau Laut terutama kegiatan penggunaan pupuk pada perkebunan dan pertanian. Adanya pengaruh hujan menyebabkan unsur-unsur pupuk yang digunakan akan terbawa ke dalam sungai atau drainase yang selanjutnya terbawa ke perairan laut. Di perairan bentuk dan unsur fosfor secara terus menerus berubah akibat proses dekomposisi dan sintesis antara bentuk organik dan anorganik yang dilakukan oleh mikroba. Perubahan ini tergantung pada suhu. Pada suhu yang mendekati titik didih perubahan polifosfat menjadi ortofosfat berlangsung cepat. Kecepatan ini juga meningkat dengan menurunnya nilai $\mathrm{pH}$ (Effendi, 2003).

\section{Nitrat}

Secara keseluruhan bahwa perairan Pulau Kerumputan dan sekitarnya masih layak untuk kelangsungan biota laut, karena kadar nitrat tidak melebihi 0,9-3,2 mg/l (Yolanda, 2016). Berdasarkan hasil penelitian sebelumnya, bahwa kadar nitrat yang didapatkan berkisar 0,5 - 0,8 mg/l (Dinas Perikanan dan Kelautan Prov. Kalsel, 2015). Nilai ini juga bila dihubungkan dengan Baku Mutu Air Laut oleh Kepmen LH No 51 Tahun 2004 maka perairan ini masih layak untuk kehidupan biota laut. Kondisi ini didukung dengan keberadaan DO di perairan laut tersebut yang berada pada kisaran yang normal. Sumber DO yang mencukupi di lokasi pengamatan dan merupakan kondisi perairan yang kondusif untuk terbentuknya nitrat sebagai nutrien $\mathrm{N}$ yang diperlukan oleh produser di air laut. Sesuai pernyataan Jones dan Lee (2005) bahwa nitrat merupakan parameter yang sangat berpengaruh terhadap kehidupan biota laut.

\section{Salinitas}

Salinitas adalah derajat konsentrasi garam yang terlarut dalam air. Hasil pengukuran salinitas menunjukkan pada kisaran antara 28 - $29 \%$ dengan rata-rata 28,34 \%o (Tabel 1). Berdasarkan kisaran tersebut menunjukkan bahwa salinitas cukup rendah. Rendahnya salinitas di area pengukuran disebabkan karena lokasi pengamatan berdekatan dengan daratan Pulau Laut Kabupaten Kotabaru dimana terdapat beberapa muara sungai yang merupakan masuknya aliran sungai ke perairan laut. Pengamatan ini tidak jauh beda dengan hasil pengukuran salinitas pada tahun 2015 yakni rata-rata nilai salinitas yang didapatkan 28 \%o (Dinas Perikanan dan Kelautan Prov. Kalsel, 2015). 

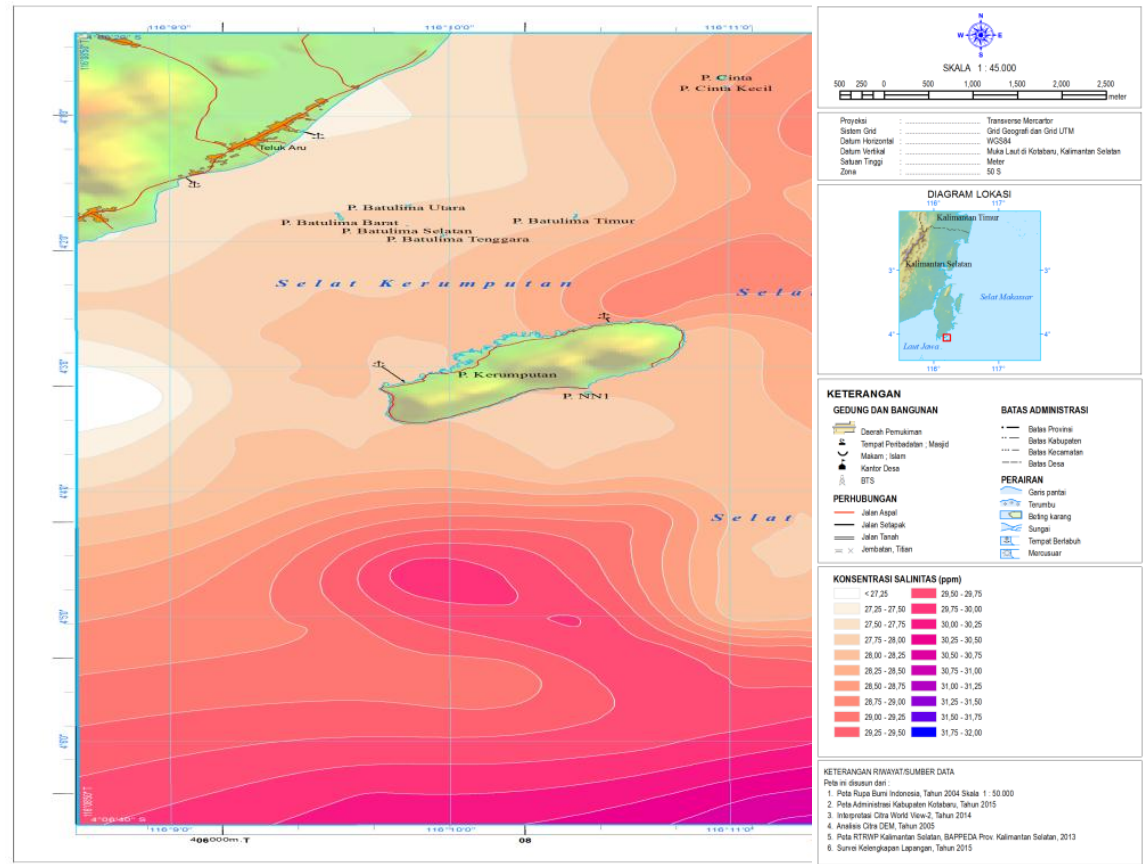

Gambar 4. Sebaran salinitas di perairan Pulau Kerumputan dan sekitarnya

\section{Derajat Keasaman $(\mathrm{pH})$}

Hasil pengukuran $\mathrm{pH}$, menunjukkan kisaran antara 7,5 - 7,7 (Tabel 1). Kondisi ini menunjukkan bahwa perairan Pulau Kerumputan memenuhi baku mutu air laut sesuai Kepmen LH No. 51 Tahun 2004, untuk kelangsungan hidup biota laut. Sebaran $\mathrm{pH}$ di setiap stasiun pengamatan tersebar merata. Tinggi rendahnya $\mathrm{pH}$ suatu perairan sangat dipengaruhi oleh kadar $\mathrm{CO}_{2}$ yang terlarut dalam perairan tersebut. Aktivitas fotosintesa merupakan proses yang sangat menentukan kadar $\mathrm{CO}_{2}$ dalam suatu perairan. Sehubungan dengan gambaran tersebut maka dapat diduga bahwa perairan lokasi studi masih ditunjang baik oleh produktivitas oksigen yang memadai. Suhu air, buangan industri dan limbah rumah tangga merupakan faktor lain yang dapat menyebabkan $\mathrm{pH}$ suatu perairan berfluktuasi.

\section{KESIMPULAN}

Karakteristik parameter fisika-kimia di Perairan Pulau Kerumputan dan sekitarnya selain dipengaruhi oleh perairan itu sendiri, juga dipengaruhi oleh lingkungan seperti pola arus diperairan tersebut. Secara umum, hasil analisa dan pengukuran parameter fisik-kimia masih layak untuk kelangsungan hidup biota laut, dimana sebagian besar parameter memenuhi standart baku mutu air laut yang sudah ditetapkan oleh Kementerian Negara Lingkungan Hidup No 51 Tahun 2004. 


\section{UCAPAN TERIMA KASIH}

Penelitian ini terlaksana atas bantuan dana Direktorat Riset dan Pengabdian Masyarakat (DRPM) Ristekdikti tahun anggaran 2017 dan Penulis mengucapkan terima kasih kepada Dekan Fakultas Perikanan dan Kelautan - Universitas Lambung Mangkurat serta Kepala Dinas Kelautan Perikanan Kabupaten Kotabaru atas dukungannya dan membantu kelancaran penelitian ini.

\section{DAFTAR PUSTAKA}

Dinas Perikanan dan Kelautan Prov. Kalsel., 2015. Laporan Akhir Perencanaan Pengembangan Pulau-Pulau Kecil Berbasis Gugus Pulau Kabupaten Kotabaru. Banjarbaru.

Effendi, H. 2003. Telaah Kualitas Air. Jurusan Managemen Sumberdaya Perairan. Fakultas Perairan dan IImu Kelautan. IPB: Bogor.

English S, Wilkinson C, Baker V. 1994. Survey Mannual For Tropical Marine Resources. Townville, Australia. ASEAN-Australia Marine Science Project: Living Coastal Resources by Australian Institute Of Marine Science.

Keputusan Menteri Lingkungan Hidup No. 51 Tahun 2004.Tentang Baku Mutu Air Laut.

Irawan A dan Lily I.S., 2013. Karakteristik Distribusi Horizontal Parameter Fisika-Kimia Perairan Permukaan di Pesisir Bagian Timur Balikpapan. Jurnal Ilmu Perikanan Tropis, 18 (2).

Jones-Lee, A., and Lee, G. F. 2005. Eutrofication (Excessive Fertilization) Water Enyclopedia: Surface and Agricultural water. Wiley, Hoboken, NJ. 107-114 pp.

Muchtar, M. 2012. Distribusi Fosfat, Nitrat dan Silikat Di Perairan Kepulauan Natuna. Pusat Penelitian Oseanografi - LIPI: Jakarta.

Odum, E. P. 1994. Dasar-dasar Ekologi Umum. Edisi Ketiga. Yogyakarta: Gadjah Mada University Press.

Patty, S. I. 2013. Distribusi Suhu, Salinitas dan Oksigen Terlarut di Perairan Kema, Sulawesi Utara. Jurnal IImiah Planax, 1(3).

Yolanda, D.S., Firman F. M., Aries D. S., 2016. Distribusi Nitrat Oksigen Terlarut, dan Suhu diPerairan Socah-Kamal Kamal Kabupaten Bangkalan. Jurnal Kelautan, 9(2), 93-98. 